\title{
Language, Form and Emotion in James Joyce's Portrait of an Artist as a Young Man: A Literary Analysis
}

Robert S.P. Jones*

School of Psychology, Bangor University, Bangor, Gwynedd, LL57 2DG, North Wales, UK

Corresponding Author: Robert S.P. Jones, E-mail: r.s.jones@bangor.ac.uk

\section{ARTICLE INFO}

Article history

Received: July 06, 2017

Accepted: October 07, 2017

Published: October 31, 2017

Volume: 8 Issue: 5

Advance access: October 2017

Conflicts of interest: None

Funding: None

\section{Key words:}

Portrait of the Artist as a Young Man,

Emotional Reaction,

Textual Analysis,

Psychological Insights,

Associative Learning,

Death-imagery

\begin{abstract}
James Joyce's Portrait of the Artist as a Young Man has fascinated readers for more than a century and there are layers of psychological meaning to be found throughout the novel. The novel is the perfect vehicle to discuss the relationship between form language and emotion as Joyce deliberately manipulated the emotional response of the reader through innovations in form and language, departing dramatically from previous literary traditions. This paper attempts to take a fresh look at the novel from a psychological perspective and seeks to examine underlying conditioning processes at work in the narrative - particularly the concept of associative learning. Understanding emotional responses to different stimuli is the bedrock of psychological investigation and 100 years after the date of its publication, Portrait of an Artist presents remarkably fresh insights into the human experience of emotion. Despite its age, Portrait of the Artist contains many contemporary psychological insights.
\end{abstract}

"I'm proud that I'm an emotionalist."

\section{INTRODUCTION}

James Joyce's Portrait of the Artist as a Young Man (POA) has fascinated readers for more than a century and the novel contains many layers of meaning that have been extensively studied since that time. Prior to the publication of POA, different forms of writing were typically separated into pre-defined categories such as sonnet, novel, script etc. With Joyce, form became more fluid and artistic, and broke away from pre-defined categories in a literary departure that changed the accepted understanding of the novel form for the next 100 years (Bowen, 1979).

The present paper aims to examine the relationship between language, form and emotion in the novel through a detailed literary analysis of the author's use of conditioned associations to manipulate the emotional responses of the reader.

In terms of method, Joyce's use of death imagery will be examined to illustrate the parallels between the conditioning

\footnotetext{
1 James Joyce, A Portrait of the Artist as a Young Man. London: Penguin, 1993 (p. 249).
}

processes described in the psychological literature and his use of language and form to shape the associations between this imagery and the presentation of the priesthood in the novel.

\section{LANGUAGE FORM AND EMOTION}

In any discussion of the interaction between language, form and emotion, the novel serves as one of the earliest examples of how writerly aesthetics can manipulate sub-conscious emotional states in the reader. With Joyce, each word is crafted and he manipulates the emotions of the reader with the skill of an artist.

Indeed, Joyce appropriately regarded himself as an artist (Ellmann, 1989), and the title of the novel clearly reflects this. This is not a portrait of "the writer" or "the author" as a young man - Joyce's artistic credentials are laid out in the most obvious manner in the title itself. He was later to present a personal insight into his relationship with form in a letter written to his patron, Harriet Shaw Weaver, on 24 June 1921:

"I have not read a work of literature for several years. My head is full of pebbles and rubbish and broken matches 
and bits of glass picked up 'most everywhere. The task I set myself technically in writing a book from eighteen different points of view and in as many styles, all apparently unknown or undiscovered by my fellow tradesmen". ${ }^{2}$

Long before J.K. Rowling was being celebrated for her skill at using a prose style that increases in complexity as Harry Potter grows older, Joyce would blend language and form to elicit an emotional response in the reader. The almost poetic, childlike, narrative of the early chapters expands incrementally towards increasingly complex descriptive prose in the later chapters. In the first chapter the writing resembles that of a sensory poem in the tradition of Shelley or Browning as the reader is exposed to Stephen's sensory reactions to his environment:

"When you wet the bed first it is warm then it gets cold. His mother put on the oilsheet. That had the queer smell. His mother had a nicer smell than his father. She played on the piano the sailor's hornpipe for him to dance (Joyce, 1993, p. 4).

Compare this with the form used later in the book when describing the experiences of Stephen as an adult:

"It was not thought nor vision though he knew vaguely that her figure was passing homeward through the city. Vaguely first and then more sharply he smelt her body. A conscious unrest seethed in his blood. Yes, it was her body he smelt, a wild and languid smell, the tepid limbs over which his music had flowed desirously and the secret soft linen upon which her flesh distilled odour and a dew" (Joyce, 1993, p. 291).

Other than the commonality of containing four consecutive sentences with a sensory theme, taken out of context, these extracts could easily have come from different sources. What unites them is a use of form that allows us a glimpse of the internal world of the main character Stephen while simultaneously giving us a glimpse of the world he inhabits. Manipulating emotion was a hallmark of Joyce's writing and much has been written about his use of stream of consciousness, and his ability to use visual and sensory language to affect the emotional reactions of the reader.

Joyce did not introduce stream of consciousness writing into the English novel but he does perhaps give it one of its clearest expositions. It is essentially a psychological process that can be distinguished from the narrative style of interior monologue by the 'stream' flowing beyond the boundaries of an organised presentation of rationality. The logical and rational restrictions often found in interior monologue tend to be of a logical nature in terms of the order of temporal progression, the sequencing of experiences and, particularly, the presence of an omniscient narrator. Stream of consciousness, on the other hand, attempts to mirror the psychological processes at work as our minds actively interpret our world through a mixture of past and present awareness. To do this, our minds flow with perceptions, impressions, observations, memories, half-thoughts and associations in an unpredictable and disjointed cascade of narrative.

2 James Joyce, letter describing his writing process 24 June 1921. British Library: Public Domain Shelfmark: Add MS 57346.
From a psychological perspective, much has been written about the relationship between stream of consciousness and theories of the unconscious. Indeed, it was the psychologist William James who provided perhaps the first description of the psychological processes underpinning stream of consciousness:

"Consciousness, then, does not appear to itself chopped up in bits. Such words as 'chain' or 'train' do not describe it fully as it presents itself in the first instance. It is nothing jointed; it flows. A 'river' or a 'stream' are the metaphors by which it is most naturally described. In talking of it hereafter let us call it the stream of thought, of consciousness, or of subjective life" (James, 1890, p. 239).

Joyce uses the stream of consciousness technique throughout the novel to beautifully capture the thoughts and feelings of Stephen as he tries to understand and appreciate his surroundings.

Although written in the $3^{\text {rd }}$ person, the novel does not have a narrator telling the reader how to react or feel. Rather, we experience Stephen's feelings first hand through his own voice. This writerly aesthetic is perfect for the evocation of emotion and Joyce employed it consistently throughout the novel:

"There was cold sunlight outside the window. He wondered if he would die. You could die just the same on a sunny day. He might die before his mother came. Then he would have a dead mass in the chapel like the way the fellows had told him it was when Little had died. All the fellows would be at the mass, dressed in black, all with sad faces. Wells too would be there but no fellow would look at him. The rector would be there in a cope of black and gold and there would be tall yellow candles on the altar and round the catafalque. And they would carry the coffin out of the chapel slowly and he would be buried in the little graveyard of the community off the main avenue of limes. And Wells would be sorry then for what he had done. And the bell would toll slowly. He could hear the tolling" (Joyce, 1993, p. 25).

\section{THE EXPERIENCE OF EMOTION}

Deliberately removing an internal narrator from the interpretation of emotion was revolutionary at the time the novel was written and pre-dates much of what is thought to be 'modern' psychological thinking (Cohn, 1978). For example, over the past two decades, contemporary psychological perspectives have slowly moved away from the dominance of a 'cognitive' emphasis on the 'accuracy' of thoughts and the centrality of an internal rational narrator for our experience. In place of this 'internal narrator', psychological perspectives are increasingly becoming influenced by eastern philosophy and nowhere is this seen as much as in the burgeoning recent interest in Mindfulness (Crane, 2008). Within this philosophical tradition the idea of an internal narrator for one's experience is regarded as a myth - rather there is a constant flow of mental experience that arises from our five senses and from our thoughts or cognitions (Williams \& Kabat-Zinn, 2011). Mindful meditation allows us to become mindfully aware of the 'flow' of this river of thoughts and sensations and contemporary psychological interventions 
increasingly emphasise the therapeutic benefit of becoming aware of these internal processes (Kabat-Zinn, 2015).

This process precisely mirrors the techniques Joyce was using in a literary context over 100 years ago. Although Joyce's writings predate much of contemporary psychological investigation, his individual insights into the human condition in general, and the unconscious mind in particular, have led to significant interest from psychology.

For example, Joyce's consideration of unconscious responses has led to a number of well-known psychoanalytical interpretations of his works centering on aspects of psychic tensions and unconscious motivations in relation to Oedipal interpretations of the text. In addition to numerous Freudian-inspired interpretations of the novel, the psychoanalyst Jacques Lacan famously allocated his twenty third seminar to the works of Joyce (Lacan, 2005). The present paper will not examine the psychoanalytic interpretations of Portrait of the Artist in any detail, but the interested reader is referred to Thurston's “James Joyce and the Problem of Psychoanalysis" for a more detailed examination of these aspects of psychological analysis (Thurston, 2004).

From a psychological perspective, the experience of emotion involves layers of complexity. Bruner describes the reading process as a flow in which readers will sometimes focus on the work itself and sometimes on their own personal reactions to what they have read (Bruner, 1986). In this context, emotion should not be thought of as a singular concept: we don't just feel anger, or sadness, or joy as a unitary experience. Rather, context is crucial in understanding emotional reactions. Throughout the process of reading two psychological processes related to emotional processing are thought to be at work simultaneously (Larsen \& Seilman, 1988). Readers may experience emotional memories as a consequence of personal reflections on the content of what has been written and may also experience fresh emotions in the moment of reading (Scheff, 1979).

Joyce was able to engender quite specific responses in the reader and such emotional complexity has been the subject of some recent psychological enquiry. For example, in a study by Cupchik et al., (1998) participants read excerpts from Joyce's short stories Dubliners and were asked to comment on their emotional reaction to what they had read. Two distinct reactions emerged: When the narrative style made it easy to identify with the characters in the story, "fresh emotions" were experienced in the moment by the reader. When the style was more descriptive, readers described emotional memories being elicited. This interesting distinction between the elicitation of emotional memories in the reader and the reader experience of "fresh emotions" being experienced during the reading of different passages is possibly relevant to Joyce's later work such as POA. The limitation of this distinction, however, lies in the assumption of a common experience of reading - a generic universal reader. The assumption of a universal reader ignores questions of race, ethnicity, gender and cultural background. It may, or may not be the case that other readers will experience the same emotional responses to similar passages but such a distinction cannot be assumed.
On the other hand, while there are clearly dangers in making assumptions about the common experience of reading, the absence of shared signifiers does not itself preclude the reader from gaining aesthetic pleasure and revelation from a writer's references or cultural "signifiers" even if that reader does not have first-hand experience of these signifiers (Borges, 1979). There is a delicate balance between universality and individuality in making assumptions about the experience of reading. The power of the imagination may well counter the need for a shared lived experience and emphasising the absence of shared meaning may inadvertently ignore important aspects of non-experiential identification in the reader.

In terms of the emotional responses to POA, perhaps the most discussed passage of POA relates to Stephen's 'epiphany' on the beach below Howth Head when he finally rejects the church in favour of a secular life. Generations of critics have pointed to the contrast between the pale, lifeless images associated with Stephen's discussions of the priesthood and the sensual images associated with his description of his encounter with the woman (Steinberg, 1980).

"Her long slender bare legs were delicate as a crane's and pure save where an emerald trail of seaweed had fashioned itself as a sign upon the flesh. Her thighs, fuller and soft-hued as ivory, were bared almost to the hips, where the white fringes of her drawers were like feathering of soft white down. Her slate-blue skirts were kilted boldly about her waist and dovetailed behind her. Her bosom was as a bird's, soft and slight, slight and soft as the breast of some dark-plumaged dove. But her long fair hair was girlish: and girlish, and touched with the wonder of mortal beauty, her face.

She was alone and still, gazing out to sea; and when she felt his presence and the worship of his eyes her eyes turned to him in quiet sufferance of his gaze, without shame or wantonness. Long, long she suffered his gaze and then quietly withdrew her eyes from his and bent them towards the stream, gently stirring the water with her foot hither and thither. The first faint noise of gently moving water broke the silence, low and faint and whispering, faint as the bells of sleep; hither and thither, hither and thither; and a faint flame trembled on her cheek.

-Heavenly God! cried Stephen's soul, in an outburst of profane joy" (Joyce 1993, p. 212).

Stephen's epiphany marks the emotional fulcrum of the novel and through this description Joyce attacks the institution of religion not with a full-frontal assault, as in some Modernist novels, but with gradual, unconscious emotional manipulation. In this single epiphany moment language, form and emotion come together in an example of the highest form of psychological narrative.

Writing about Joyce's ability to condition the emotional responses of the reader, Bowen, for example, appears to assert that these responses are universal:

"By use of a narrative voice removed from Stephen's perspective but yet a part of it, the reader's consciousness is drawn into Stephen's so that the epiphanies are shared and the reader has a sense of having created along with Stephen 
the perspective from which the revelations proceed. Thus, like Stephen, we have been conditioned for his vision at the end of chapter four by all the preceding events of the book" (Bowen, 1979, p. 486).

Assuming a common response to this passage, however, negates the alternative perspectives beyond Stephen's male gaze and ignores a different emotional response in other readers (Fetterley, 1978). Not only might there be an alternative perspective on this passage beyond the "phallic centric" hegemony of the heterosexual male, but Joyce would also have been aware of a significant probable readership amongst the Catholic clergy and congregation of early 20th Century Ireland. We cannot know, and should not speculate, on whether Joyce intentionally wrote for an assumed generic male reader but even within this limited category, there could be significant differences in responses on the basis of religious faith alone.

\section{CONDITIONING PROCESSES}

Conditioning theory in psychology can, perhaps, provide some insight into the balance between universality and individuality in this regard. For decades, psychologists have argued for a common mechanism for conditioning without assuming a homogenous response. Ignoring individual experience is an error that held back early research on the understanding of emotional conditioning (Cooper, Heron \& Heward, 2007), but contemporary psychological theory embraces the concept of a shared conditioning process while acknowledging a unique and personal response to that process (Delamater, 2012).

Of most importance in this analysis is the readers' ability to identify with Stephen, irrespective of the reader's personal history, perspective or background. Whether or not we, as readers, personally identify with any particular 'gaze' as we read this passage, we can appreciate how Stephen's emotions have developed to the point where he associates the image of the woman as contrasting with the with pale, lifeless, symbols of the priesthood that he has been exposed to up to this point:

"This was the call of life to his soul not the dull gross voice of the world of duties and despair, not the inhuman voice that had called him to the pale service of the altar" (Joyce, 1993 p. 169). As Smith argues, through such skilful manipulation of the novel's rhythmic image clusters and motifs, Joyce forces us to observe what Smith calls "the dynamic patterns of association among images on the page [which] reflect the developing structure of Stephen's mind" (Smith, 1980, p. 17).

Joyce was not alone amongst artists in manipulating layers of emotions, often simultaneously, but he was one of the first novelists in the $20^{\text {th }}$ Century to achieve this so subtly (Keen, 2007). Indeed, it is the subtlety of Joyce's language that is the hallmark of his ability to manipulate emotions in the reader (Fernihough, 2007). As Stephen grows older, Joyce presents a growing pretentiousness emerging in the forthright and ambitious young man. As Stephen prepares to leave Ireland in the final chapter he aspires "to forge in the smithy of my soul the uncreated conscience of my race"
(Joyce, 1993, p. 317). Here in what is perhaps the most famous quote of the entire book, we see Joyce's subtle use of language to create an unsettling ambiguity. Joyce does not write: "To construct in the workshop of my soul, the uncreated conscience of my race". By associating the word "forge" with "smithy" Joyce elicits the image of a blacksmith industrially working to produce something valuable from crafting basic elements of fire and iron. Beneath the surface, however, another association is at work: there is an alternative interpretation of the word "forge" and the subtle hint at something fraudulent is no accident. The awareness of Stephen leaving Ireland to create something duplicitous is imperceptibly added as a layer of concurrent meaning by Joyce's subtle use of ambiguous terminology.

Such subtle manipulation of language and form is a characteristic of Joyce's writing and on the rare occasions when the language use is less subtle and more explicit the linguistic expression seems almost too obviously stated. But this more explicit focus is not accidental and the departure from the more subtle associations of language and emotion at key moments in the book is a deliberate mechanism used to establish new associations. There are many such examples in the book but we will examine a single, illustrative example - the association of the priesthood with images of death and decay.

\section{DEATH IMAGES}

As was the case with many of the early Modernist novels, Portrait of the Artist questioned established social institutions and, in the case of Joyce, Irish Nationalism and Roman Catholicism were particularly targeted. The novel centers on Stephen's relationship with the Church and his decision about whether to enter the priesthood or follow a secular path. While his secular choices abound with images of colour, warmth and sensuality, his alternative choices elicit feelings of death, coldness and decay. From a psychological perspective, here is further use of the psychological process of associative learning (Davey, 1987). In terms of the use of language to manipulate emotion, Joyce uses a familiar trope (the image of a human skull) as the basis for subtle re-conditioning. The image of the skull had been a familiar visual image since the days of Renaissance art (as in the memento mori in early still life scenes) and took on extra emotional impact in Gothic literature. Joyce required a previous exposure to the pairing of skull with images of death and decay to allow for a new conditioning process to work. While, as we have seen, there are dangers in assuming the existence of a generic, universal reader, all readers are likely to have been previously exposed to images of a skull used to elicit a primordial emotional response. Throughout the novel Joyce subtly shifts this association from macabre horror to banal servitude. Eventually the skull-image will represent a cold, life-denying future but the process used to 're-condition' this association shows the relationship between language form and emotion as the novel progresses.

As a young child, Stephen's first encounter with the rector of Clongowes Wood College is clearly associated with the death image of a skull: 
"He saw the rector sitting at a desk writing. There was a skull on the desk and a strange solemn smell in the room like the old leather of chairs. His heart was beating fast on account of the solemn place he was in and the silence of the room: and he looked at the skull and at the rector's kind-looking face" (Joyce, 1993, p. 67).

The priest deals with Stephen kindly but before leaving the office there is a third reference to the skull:

"The rector held his hand across the side of the desk where the skull was and Stephen, placing his hand in it for a moment, felt a cool moist palm. Good day now, said the rector, withdrawing his hand and bowing" (Joyce, 1993, p. 68).

Joyce is far from subtle here. Knowing his readership will already have clear emotional responses associated with skull images, Joyce unambiguously pairs that image with the priesthood. Along with "a strange solemn smell", "silence" and a "cool moist palm", negative associations are being built up beneath the surface that ostensibly identifies the priest as "kindly".

This process mirrors what we know of effective conditioning processes. Within conditioning theory, although future pairings may be very subtle, the initial pairing of two stimuli must have sufficient strength to be salient and explicit (Hull, 1951). For Joyce, if the reader is later to associate the priesthood with the cold silence of the grave then the initial pairing of relevant stimuli must be unambiguous. As such, Joyce cannot afford his characteristic subtlety at this early stage and the unambiguous pairing of the priesthood with the skull is necessary to establish the association. Later references can then be less explicit as the associations serve to elicit the emotional response rather than to establish it. More subtle associations can be made in subsequent pairings when, for example, as an adolescent Stephen is summoned to the office of the Director of Belvedere College who, with a "grave and cordial voice" asks him if he has ever considered joining the priesthood. The subtle associations of the word "grave" are less obvious than in the rector's office as are other death-like references such as the dying of the light and the noose-like looping of the blind cord in the priest's fingers. Stephen finds his eyes roaming from "the waning of the long summer daylight" to the "slow deft movements of the priestly fingers" as the skull-image is again presented but, this time, in a more subtle manner:

"The priest's face was in total shadow, but the waning daylight from behind him touched the deeply grooved temples and the curves of the skull" (Joyce, 1993, p. 189).

On leaving the office Stephen considers the proposal and once again, the priest's face is associated with images of mirthless decay:

"Smiling at the trivial air he raised his eyes to the priest's face and, seeing in it a mirthless reflection of the sunken day, detached his hand slowly which had acquiesced faintly in the companionship. As he descended the steps the impression which effaced his troubled self-communion was that of a mirthless mask reflecting a sunken day from the threshold of the college" (Joyce, 1993, p. 198).

Now that the stimuli have been successfully paired, it only requires a brief exposure to images associated with skulls (such as "mirthless mask") to elicit the desired emotional re- action (Kamin, 1965). As Stephen continues to consider the option of becoming a priest and contemplates his possible new name ("The Reverend Stephen Dedalus, S.J."), he immediately thinks of an "eyeless face" and a "spectre":

"His name in that new life leaped into characters before his eyes and to it there followed a mental sensation of an undefined face or colour of a face. The colour faded and became strong like a changing glow of pallid brick red. Was it the raw reddish glow he had so often seen on wintry mornings on the shaven gills of the priests? The face was eyeless and sour-favoured and devout, shot with pink tinges of suffocated anger. Was it not a mental spectre of the face of one of the jesuits whom some of the boys called Lantern Jaws and others Foxy Campbell?" (Joyce, 1993, p. 199).

Later in the novel when Stephen has a falling out with Cranly he comments on the death-like aspects of his friend's face and describes his "priest-like" face and lips:

"Why was it that when he thought of Cranly he could never raise before his mind the entire image of his body but only the image of the head and face? Even now against the grey curtain of the morning he saw it before him like the phantom of a dream, the face of a severed head or deathmask, crowned on the brows by its stiff black upright hair as by an iron crown. It was a priest-like face, priest-like in its palor, in the wide winged nose, in the shadowings below the eyes and along the jaws, priest-like in the lips that were long and bloodless and faintly smiling" (Joyce, 1993, p. 219).

The continuous presentation of similar images has a cumulative effect as the images of death come to elicit emotions associated with dullness and servitude.

"This was the call of life to his soul not the dull gross voice of the world of duties and despair, not the inhuman voice that had called him to the pale service of the altar" (Joyce, 1993, p. 169).

At this stage, the brief exposure to the relevant stimuli begins to be processed underneath the level of full conscious awareness. The reader may or may not be fully aware of the conditioning process that has led to the association of words like "inhuman" and "pale" in the previous quote. Crucially, emotional responding no longer depends on a conscious awareness of these pairings and any negative responses to the life of the priesthood can be experienced simply at an emotional rather than a cognitive level. Here is the final culmination of the fluid and artistic use of form and structure whereby elements of form previously defined as either visual imagery, poetry, drama or prose combine and interact to change the very nature of what was previously defined as a novel (Bowen, 1979). Here truly is a portrait of an artist at work.

\section{CONCLUSION}

The analysis undertaken in this paper looked at the manipulation of the reader response through the process of emotional conditioning. The shaping of readers' emotions throughout POA is one of Joyce's greatest achievements. Through the manipulation of language and form, the reactions of the reader to the text constantly shift to reflect the changing emotions of Stephen Dedalus. Joyce achieved this 
by a combination of literary techniques: The removal of an internal narrator allows the reader to experience Stephen's emotions directly, and increasing the complexity of the prose style as the character grows older allows the development of reader empathy to be continually refreshed as Stephen matures. Stream of consciousness techniques present the emotionally raw emotions of the character from the perspective of the emerging consciousness of his experience. Through the analysis of the use of death images by Joyce, we can see how Stephen's experience of the world is transmitted directly to the reader through a process of psychological conditioning that perfectly matches the techniques of associative learning. Detailed literary analysis has shown how this conditioning process moves through various stages of subtlety to a stage where the manipulation of the emotional response to death imagery is almost below the level of the reader's conscious awareness.

The use of death imagery is the focus of the present paper but is only one of many examples of Joyce's use of associative learning techniques and these too are deserving of further study. It is a tribute to Joyce's ability to understand the psychological processes underlying the experience of emotion that his works continue to fascinate psychologists to this day.

\section{REFERENCES}

Borges, J. L. (1979). "The Congress," The Book of Sand, translated by Norman Thomas di Giovanni. New York: E. P. Dutton.

Bowen, Z R. (1979). 'Epiphanies, Stephen's Diary, and the Narrative Perspective of "A Portrait of the Artist as a Young Man. James Joyce Quarterly, 16, 4, 485-488.

Brune, J. (1986). Actual minds, possible worlds. Cambridge, MA: Harvard University Press.

Centola, S. R. (1985). "'The White Peace of the Altar": White Imagery in James Joyce's 'A Portrait of the Artist as a Young Man'. South Atlantic Review, 50, 93-106.

Cohn, D. (1978). Transparent Minds: Narrative Modes for Presenting Consciousness in Fiction. Princeton: Princeton University Press.

Cooper, J. O., Heron T. E., \& W. Heward, W. (2007). Applied Behavior Analysis. Upper Saddle River, NJ: Pearson 2007.

Crane, R. (2009). Mindfulness-Based Cognitive Therapy: Distinctive Features. Hoboken: Taylor \& Francis.

Cupchik, G. C., Oatley, K. \& Vorderer, P. (1998). 'Emotional effects of reading excerpts from short stories by James Joyce'. Poetics, 25, 363-377.

Davey, G. (Ed.), Cognitive Processes and Pavlovian Conditioning in Humans Chichester: John Wiley \& Sons.
Dawson, M. E. (1973). Can classical conditioning occur without contingency learning? A review and evaluation of the evidence. Psychophysiology, 10, 82-86.

Delamater, A. R. (2012). On the nature of CS and US representations in Pavlovian learning. Learning and Behavior, 40, 1-23.

Ellmann, R. (1989). James Joyce. (Oxford: Oxford University Press. 1989.

Fetterley, J. (1978). The Resisting Reader: A Feminist Approach to American Fiction. Bloomington: Indiana University Press.

Fernihough, A. (2007). Consciousness as a stream. in The Cambridge companion to the modernist novel, ed. by Morag Shiach, Cambridge: Cambridge University Press.

Goldhill, S. (2015). The Buried Life of Things. Cambridge University Press Cambridge UK.

Hull, C. L. (1951). Essentials of Behavior. New Haven: Yale University Press.

James, W. (1890). The Principles of Psychology. New York, NY: Henry Holt, p. 239).

Joyce, J. (1993). A Portrait of the Artist as a Young Man. (London: Penguin, 1993).

Joyce, J. (1921) letter describing his writing process, 24 June 1921. British Library: Public Domain Shelfmark: Add MS 57346.

Kabat-Zinn, J. (2005). Wherever you go, there you are: mindfulness meditation in everyday life. Hyperion: New York, N.Y.

Kamin, L. J. (1965). Temporal and intensity characteristics of the conditioned stimulus. In W. F. Prokasy (Ed.), Classical Conditioning: A Symposium. New York: Appleton-Century-Crofts.

Keen, S. (2007). Empathy and the Novel. (Oxford: Oxford University Press.

Lacan, J. (2005). Le séminaire livre XXIII: le sinthome. Paris: Seuil.

Larsen, S. F., \& Seilman, U. (1988). Personal remindings while reading literature'. Text, 8, 411-429.

Scheff, T. J. (1979). Catharsis in healing, ritual, and drama. (Berkeley: University of California Press.

Smith, J. B. (1980). Imagery and the Mind of Stephen Dedalus. Lewisburg: Bucknell UP.

Steinberg, E. R. (1980). The Bird-Girl in A Portrait as Synthesis: The Sacred Assimilated to the Profane. James Joyce Quarterly, 17, 149-163.

Thurston, L. (2004). James Joyce and the Problem of Psychoanalysis. Cambridge: Cambridge University Press.

Williams, M. G., \& Kabat-Zinn, J. (2011). Mindfulness: diverse perspectives on its meaning, origins, and multiple applications at the intersection of science and dharma'. Contemporary Buddhism, 12, 1. 